\title{
OPTIMIZATION OF PERCENTAGES OF STEEL AND GLASS FIBER REINFORCED CONCRETE
}

\author{
Praveen Kumar Goud.E ${ }^{1}$, Praveen K.S ${ }^{2}$ \\ ${ }^{1}$ Student, Mtech, structural engineering, SRM University, Kattankulathur, 603 203, TamilNadu, India \\ ${ }^{2}$ Assistant Professor, Department of Civil Engineering, Faculty of Engineering and Technology, SRM University, \\ Kattankulathur, 603 203, TamilNadu, India
}

\begin{abstract}
Cementitious matrices are the fragile materials that possess a low tensile strength. The addition of fibers randomly distributed in these matrices improves their resistance to cracking, substantially. However, the incorporation of fibers into a plain concrete disrupts the granular skeleton and quickly causes problems of mixing as a result of the loss of mixture workability that will be translated into a difficult concrete casting in site. This study was concerned on the one hand with optimizing the fibers reinforced concrete mixes in the fresh state, and on the other hand with assessing the mechanical behaviour of this mixture in the hardened state, in order to establish a compromise between the two states. In this paper optimization of fibers by using different percentages in steel and glass fiber reinforced concrete of grade M 70 have been studied. It optimizes $1.5 \%$ for steel Fiber content and $1 \%$ for glass fiber content by the volume of cement is used in concrete.
\end{abstract}

Keywords: fibers, fragile materials, cracking, substantially

\section{INTRODUCTION}

Fibre reinforced concrete (FRC) is Portland cement concrete reinforced with more or less randomly distributed fibres. In FRC, thousands of small fibres are dispersed and distributed randomly in the concrete during mixing, and thus improve concrete properties in all directions. FRC is cement- based composite material that has been developed in recent years. It has been successfully used in construction with its excellent flexural-tensile strength, resistance to spitting, impact resistance and excellent permeability and frost resistance. It is an effective way to increase toughness, shock resistance and resistance to plastic shrinkage cracking of the mortar. Fibre is a small piece of reinforcing material possessing certain characteristics properties. They can be circular, triangular or flat in cross-section. The fire is often described by a convenient parameter called — aspect ratioll. The aspect ratio of the fibre is the ratio of its length to its diameter. The principle reason for incorporating fibres into a cement matrix is to increase the toughness and tensile strength and improve the cracking deformation characteristics of the resultant composite. For FRC to be a viable construction material, it must be able to compete economically with existing reinforcing system. FRC composite properties, such as crack resistance, reinforcement and increase in toughness are dependent on the mechanical properties of the fibre, bonding properties of the fibre and matrix, as well as the quantity and distribution within the matrix of the fibres

\section{TYPES OF FIBERS}

\subsection{Steel Fiber Reinforced Concrete}

Steel fibre reinforce concrete is a composite material which is made up from cement concrete mix and steel fibres as a reinforcing. The steel fibres, which are uniformly distributed in the cementations mix. This mix, have various volume fractions, geometries, orientations and material properties. It has been shown in the research that fibres with low volume fractions $(<1 \%)$, in fibre reinforced concrete, have an insignificant effect on both the compressive and tensile strength. Generally SFRC is very ductile and particularly well suited for structures which are required to exhibit:-

- High fatigue strength resistance to impact, blast and shock loads

- Shrinkage control of concrete

- Tensile strength, very high flexural, shear

- Erosion and abrasion resistance to splitting

- Temperature resistance, high thermal

- Earth quake resistance

The degree of improvement gained in any specific property exhibited by SFRC is dependent on a number of factors that include:-

- Concrete mix and its age

- Steel fiber content, volume fraction

- Fiber geometry, its aspect ratio (length to diameter ratio) and bond characteristics volume fraction

\subsection{Glass Fiber Reinforced Concrete}

Glass fibre-reinforced concrete is (GFRC) basically a concrete composition which is composed of material like cement, sand, water, and admixtures, in which short length 
discrete glass fibers are dispersed. Inclusion of these fibres in these composite results in improved tensile strength and impact strength of the material.GFRC has been used for a period of 30 years in several construction elements but at that time it was not so popular, mainly in non-structural ones, like facing panels (about $80 \%$ of the GRC production), used in piping for sanitation network systems, decorative non-recoverable formwork, and other products. At the beginning age of the GFRC development, one of the most considerable problems was the durability of the glass fiber, which becomes more brittle with time, due to the alkalinity of the cement mortar. After some research, significant improvement have been made, andpresently, the problem is practically solved with the new types of alkaliresistant (AR resistance) glass fibers and with mortar additives that prevent the processes that lead to the embrittlement of GFRC.

\section{MIX RATIO}

Mix design using $12.5 \mathrm{~mm}$ size graded aggregates:

Characteristic strength $=70 \mathrm{MPa}$.

Target mean strength $=70+1.65 \times 6=80 \mathrm{Mpa}$.

Maximum size of graded aggregate $=12.5 \mathrm{~mm}$

Bulk density of loose coarse aggregate $=1494 \mathrm{~kg} / \mathrm{m} 3$

Bulk density of loose fine aggregate $=1460 \mathrm{~kg} / \mathrm{m} 3$

Volume of fine/coarse aggregate ratio $=52 / 48$

Volume ratio of fine aggregates to total aggregates $(\mathrm{s} / \mathrm{a})=$ $52 / 100$

Determination of Coarse aggregate:

Assume P.F = 1.12

Amount of coarse aggregate, $\mathrm{W} g=$ P.F x W gL (1-s/a)

$=1.12 \times 1494 \times(1-0.52)$

$=803.17 \mathrm{~kg} / \mathrm{m}^{3}$

Determination of fine aggregate:

Amount of fine aggregates, W s $=$ P.F x W sL (s/a)

$=1.12 \times 1460 \times(0.52)$

$=850.3 \mathrm{~kg} / \mathrm{m}^{3}$

Determination of cement:

$\mathrm{C}=\mathrm{f}^{\prime} \mathrm{c} / 20$

Given $0.14 \mathrm{Mpa}=20 \mathrm{psi}$

Hence $\mathrm{C}=80 / 0.14=571.42 \mathrm{~kg} / \mathrm{m}^{3}$

Determination of water:

Water/cement ratio for $26.6 \mathrm{Mpa}=0.25$

Hence quantity of water required $=571.42 \times 0.25=142.85$

$\mathrm{kg} / \mathrm{m} 3$

Determination of fly ash:

$\mathrm{V}$ pf $+\mathrm{V}$ pb $=1-\mathrm{W}$ g / (1000 x G g $)-\mathrm{W} \mathrm{s} /(1000 \mathrm{x}$

$\mathrm{G} \mathrm{f})-\mathrm{C} /(1000 \times \mathrm{G} \mathrm{c})-\mathrm{W} w \mathrm{w} /(1000 \mathrm{x}$

$\mathrm{G}$ w )-V a

$=1-803.17 /(1000 \times 2.92)-850.3 /$

$(1000 \times 2.63)-571.42 /(1000 \times$

$3.10)-142.85 /(1000 \times 1)-0.015$

$=0.02 \mathrm{~kg} / \mathrm{m}^{3}$
Total weight of Pozzolanic material(W pm ):

$\mathrm{V} p \mathrm{pf}+\mathrm{V} \mathrm{pb}=(1+\mathrm{W} / \mathrm{F}) \times \mathrm{A} \% \times \mathrm{W} \mathrm{pm} /(1000 \times \mathrm{G} \mathrm{f})$

$\mathrm{W} \mathrm{pm}=(\mathrm{V}$ pf $+\mathrm{V}$ pb $) \mathrm{x}$

$(1000 \times \mathrm{G} \mathrm{f}) /((1+\mathrm{W} / \mathrm{F}) \times \mathrm{A} \%)$

$=0.02 \times(1000 \times 2.19) /(1+0.25)$

$=35.46 \mathrm{~kg} / \mathrm{m}^{3}$

Determination water required for fly ash

(W wf ):

$\mathrm{W} \mathrm{wf}=\mathrm{W} / \mathrm{F} \times \mathrm{W}$ pm

$=0.25 \times 35.46=8.86 \mathrm{~kg} / \mathrm{m}^{3}$

Determination of S.P dosage (W sp );

S.P dosage $=1.8 \%$ of $(571.42+35.46)=10.92 \mathrm{~kg} / \mathrm{m} 3$

Water content in S.P $=(1-0.4) \times 10.92=6.55 \mathrm{~kg} / \mathrm{m}^{3}$

Total water content $=142.85+8.86-6.55=145.16 \mathrm{~kg} / \mathrm{m} 3$

Water binder ratio $(\mathrm{W} / \mathrm{B})=145.16 /(571.42+35.46)=$ 0.239 .

Table 1: mix proportions

\begin{tabular}{|l|l|l|l|l|l|l|}
\hline & $\begin{array}{l}\text { Ceme } \\
\text { nt }\end{array}$ & $\begin{array}{l}\text { Fine } \\
\text { aggreg } \\
\text { ate }\end{array}$ & $\begin{array}{l}\text { Coarse } \\
\text { aggreg } \\
\text { ate }\end{array}$ & $\begin{array}{l}\text { Fly } \\
\text { ash }\end{array}$ & sp & $\begin{array}{l}\text { Wate } \\
\text { r w/b }\end{array}$ \\
\hline $\begin{array}{l}\text { Quantity } \\
\left(\mathrm{kg} / \mathrm{m}^{3}\right)\end{array}$ & $\begin{array}{l}571.4 \\
2\end{array}$ & 850.43 & 803.17 & $\begin{array}{l}35.4 \\
6\end{array}$ & $\begin{array}{l}10.9 \\
2\end{array}$ & $\begin{array}{l}145 . \\
16\end{array}$ \\
\hline $\begin{array}{l}\text { Proporti } \\
\text { ons }\end{array}$ & 1 & 1.48 & 1.40 & $\begin{array}{l}0.06 \\
2\end{array}$ & $\begin{array}{l}0.01 \\
9\end{array}$ & $\begin{array}{l}0.23 \\
9\end{array}$ \\
\hline
\end{tabular}

\section{OPTIMIZATION}

From a material and structural point of view, there is a delicate balance in optimizing the bond between the fiber and the matrix. ? If the fibers have a weak bond with the matrix, they can slip out at low loads and do not contribute very much to bridge the cracks. In this situation, the fibers do not increase the toughness of the system. If If the bond with the matrix is too strong, many of the fibers may break before they dissipate energy by sliding out. In this case, the fibers behave as non-active inclusions leading to only marginal improvement in the mechanical properties.

\subsection{Steel Fiber Optimization}

Different percentages of steel fibers are used in concrete of grade $\mathrm{m} 70$ like $0.5 \%, 1 \%, 1.5 \%, 2 \%$

Table 2: optimization of steel fibers by using different fibers

\begin{tabular}{|l|l|l|l|}
\hline $\begin{array}{l}\text { Percentage } \\
\text { of steel } \\
\text { fibers }\end{array}$ & $\begin{array}{l}3^{\text {rd }} \\
\text { compressive } \\
\text { strength } \\
\left(\mathrm{N} / \mathrm{mm}^{2}\right)\end{array}$ & $\begin{array}{l}7^{\text {th }} \\
\text { compressive } \\
\text { strength } \\
\left(\mathrm{N} / \mathrm{mm}^{2}\right)\end{array}$ & $\begin{array}{l}28^{\text {th }} \\
\text { compressive } \\
\text { strength } \\
\left(\mathrm{N} / \mathrm{mm}^{2}\right)\end{array}$ \\
\hline 0.5 & 26 & 44 & 67 \\
\hline 1 & 27 & 45 & 69 \\
\hline $\mathbf{1 . 5}$ & 31 & 48 & 74 \\
\hline 2 & 25 & 46 & 71 \\
\hline
\end{tabular}

\subsection{Glass fiber optimization}

Different percentages of glass fibers are used in concrete of grade $\mathrm{m} 70$ like $0.5 \%, 1 \%, 1.5 \%, 2 \%$ 
Table 3: Optimization Of Glass Fibers By Using Different

\begin{tabular}{|c|c|c|c|}
\hline \multicolumn{4}{|c|}{ Fibers } \\
\hline $\begin{array}{l}\text { Percentag } \\
\mathrm{e} \text { of steel } \\
\text { fibers }\end{array}$ & $\begin{array}{l}3^{\text {rd }} \\
\text { compressiv } \\
\text { e strength } \\
\left(\mathrm{N} / \mathrm{mm}^{2}\right)\end{array}$ & $\begin{array}{l}7^{\text {th }} \\
\text { compressiv } \\
\text { e strength } \\
\left(\mathrm{N} / \mathrm{mm}^{2}\right)\end{array}$ & $\begin{array}{l}28^{\text {th }} \\
\text { compressiv } \\
\text { e strength } \\
\left(\mathrm{N} / \mathrm{mm}^{2}\right)\end{array}$ \\
\hline 0.5 & 25 & 42.5 & 68 \\
\hline 1 & 29 & 47 & 72 \\
\hline 1.5 & 27 & 44 & 69 \\
\hline 2 & 25 & 43 & 67 \\
\hline
\end{tabular}

\section{RESULTS \& DISCUSSIONS}

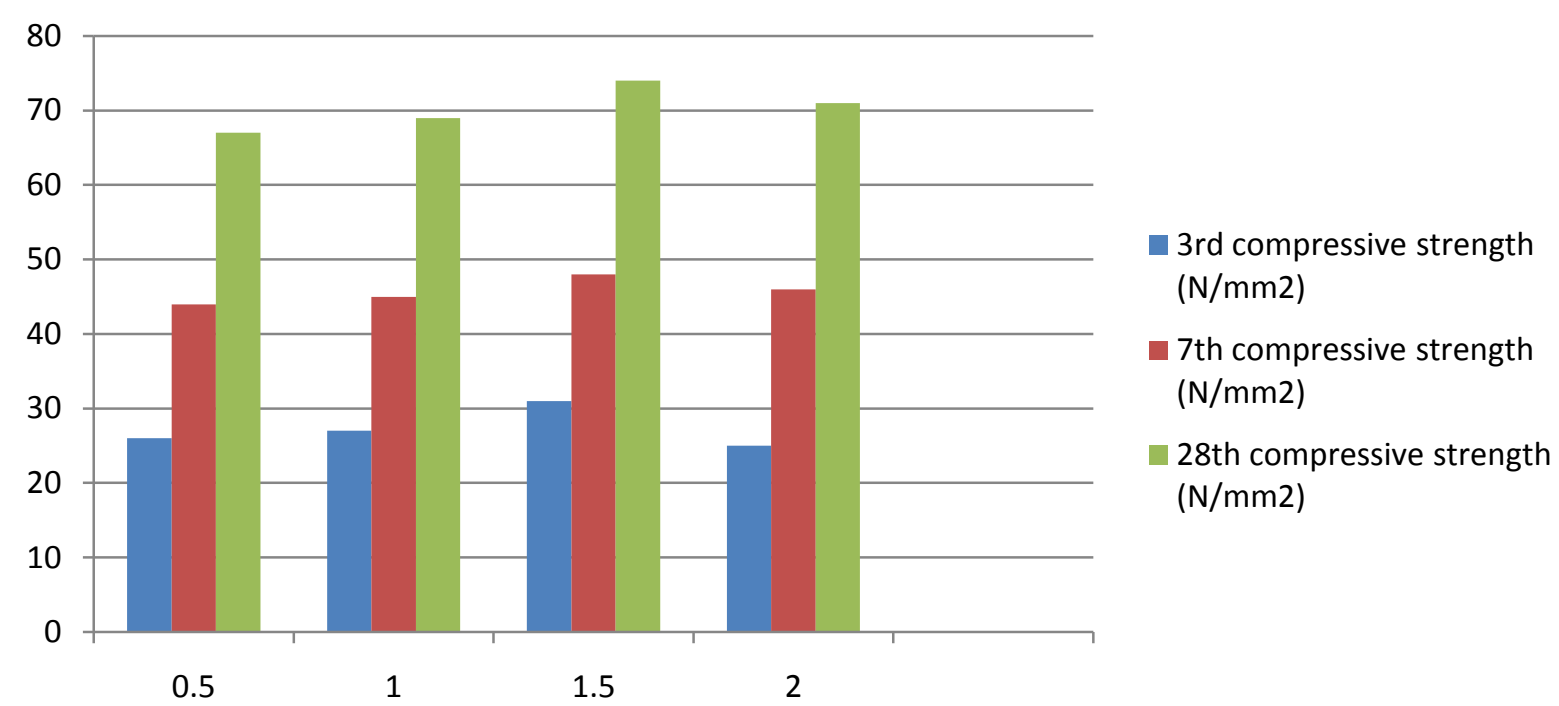

Chart 1: Comparison Of Compressive Strength Different Percentages of Steel Fiber Reinforced Concrete

In the above graph comparison of compressive strength of different percentage of steel fibers added to optimize the grade $\mathrm{m} 70$ concrete. The compressive strength of $0.5 \%$ of at 3 days is $26 \mathrm{~N} / \mathrm{mm} 2,7$ days is $44 \mathrm{~N} / \mathrm{mm} 2$ and 28 days is $67 \mathrm{~N} / \mathrm{mm} 2$ and The compressive strength of $1 \%$ of at 3 days is $27 \mathrm{~N} / \mathrm{mm} 2,7$ days is $45 \mathrm{~N} / \mathrm{mm} 2$ and 28 days is 69 $\mathrm{N} / \mathrm{mm} 2$, The compressive strength of $1.5 \%$ of at 3 days is 31 $\mathrm{N} / \mathrm{mm} 2,7$ days is $48 \mathrm{~N} / \mathrm{mm} 2$ and 28 days is $74 \mathrm{~N} / \mathrm{mm} 2$, The compressive strength of $2 \%$ of at 3 days is $25 \mathrm{~N} / \mathrm{mm} 2,7$ days is $46 \mathrm{~N} / \mathrm{mm} 2$ and 28 days is $71 \mathrm{~N} / \mathrm{mm} 2$.

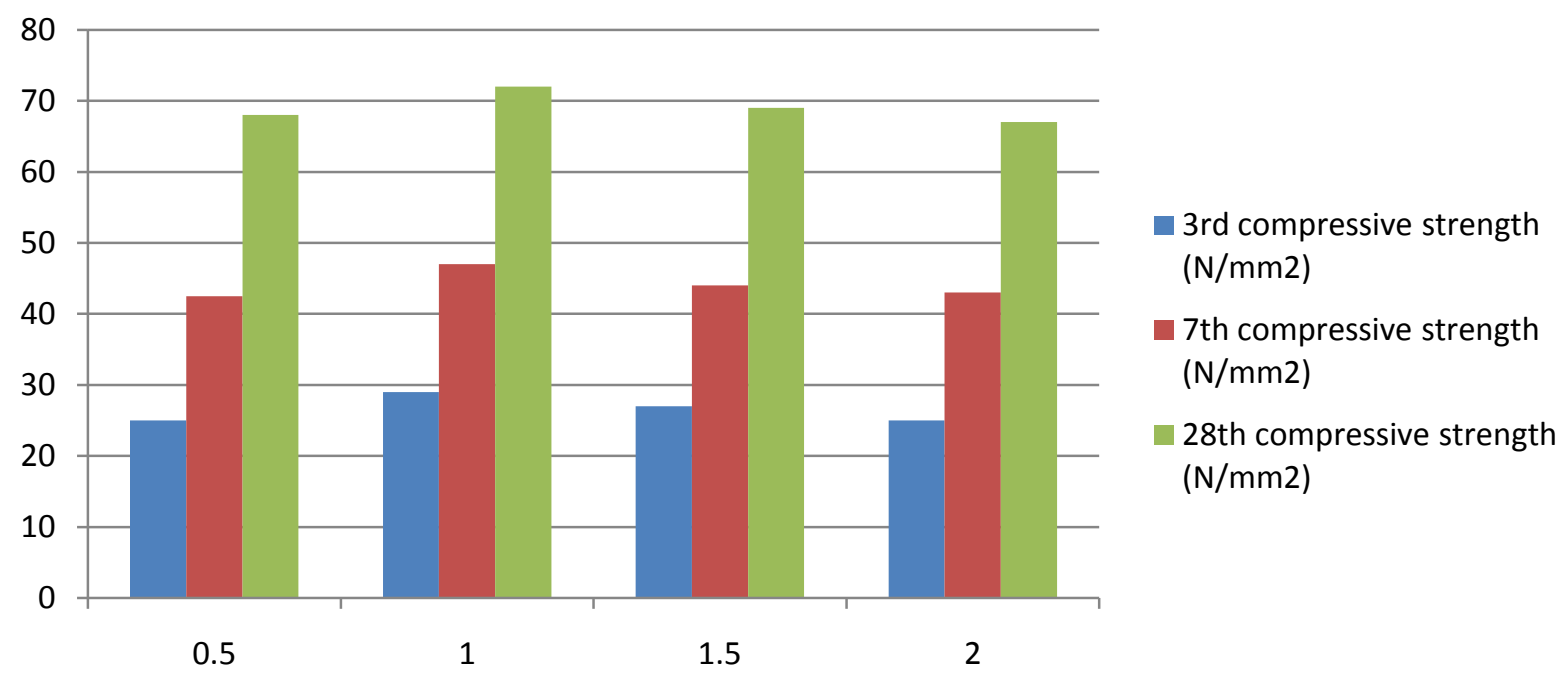

Chart 2: Comparison Of Compressive Strength Different Percentage of Glass Fiber Reinforced Concrete 
In the above graph comparison of compressive strength of different percentage of glass fibers added to optimize the grade $\mathrm{m} 70$ concrete. The compressive strength of $0.5 \%$ of at 3 days is $25 \mathrm{~N} / \mathrm{mm} 2,7$ days is $42 \mathrm{~N} / \mathrm{mm} 2$ and 28 days is $68 \mathrm{~N} / \mathrm{mm} 2$ and The compressive strength of $1 \%$ of at 3 days is $29 \mathrm{~N} / \mathrm{mm} 2,7$ days is $47 \mathrm{~N} / \mathrm{mm} 2$ and 28 days is 72 $\mathrm{N} / \mathrm{mm} 2$, The compressive strength of $1.5 \%$ of at 3 days is 27 $\mathrm{N} / \mathrm{mm} 2,7$ days is $44 \mathrm{~N} / \mathrm{mm} 2$ and 28 days is $69 \mathrm{~N} / \mathrm{mm} 2$, The compressive strength of $2 \%$ of at 3 days is $25 \mathrm{~N} / \mathrm{mm} 2,7$ days is $43 \mathrm{~N} / \mathrm{mm} 2$ and 28 days is $67 \mathrm{~N} / \mathrm{mm} 2$.

\section{RESULTS}

From the above results and comparison following point are observed:

- $\quad$ The compressive strength of steel fiber reinforced concrete of grade M70 by using $0.5 \%$ at 28 days is $67 \mathrm{~N} / \mathrm{mm} 2$, by using $1 \%$ at 28 days is $69 \mathrm{~N} / \mathrm{mm} 2$, by using $1.5 \%$ at 28 days is $74 \mathrm{~N} / \mathrm{mm} 2$, by using $2 \%$ at 28 days is $71 \mathrm{~N} / \mathrm{mm} 2$. When compared to all percentages steel fibers optimizes $1.5 \%$.

- The compressive strength of glass fiber reinforced concrete of grade $\mathrm{M} 70$ by using $0.5 \%$ at 28 days is $68 \mathrm{~N} / \mathrm{mm} 2$, by using $1 \%$ at 28 days is $72 \mathrm{~N} / \mathrm{mm} 2$, by using $1.5 \%$ at 28 days is $69 \mathrm{~N} / \mathrm{mm} 2$, by using $2 \%$ at 28 days is $67 \mathrm{~N} / \mathrm{mm} 2$. When compared to all percentages steel fibers optimizes $1 \%$.

\section{REFERENCES}

[1]. Cement \& Concrete Association of New Zealand. 2009. Information Bulletin: IB 39, Fibre Reinforced Concrete

[2]. J. H. Morton. Developing Fiber Application in Structural Concrete. Buckeye Technology, 1001 Tillman St., Memphis, TN 38108, USA.

[3]. R. B. Abdul-Ahad and O. Q. Aziz. 1999. Flexural Strength of Reinforced Concrete T-Beans with Steel Fibers. Cement and Concrete Compositions. Volume 21 Issue 4. pp 263-268.

[4]. M. Yakhlaf, M. Safiuddin, and K. A. Soudki. 2013. Properties of Freshly Mixed Carbon Fibre Reinforced Self-Consolidating Concrete. Construction and Building Materials, Vol. 46, pp. 224-231.

[5]. D. D. L. Chung. 2000. Cement Reinforced with Short Carbon Fibers: A Multifunctional Material. Composites: 31 (B) 511-526.

[6]. P. W. Chen and D. D. L. Chung. 1992. Concrete Reinforced with up to $2 \%$ of Short Carbon Fibers. State University of New York at Buffalo, USA.

[7]. T. Ochi, S. Okubo, K. Fukui .2007. Developed of Recycle PET Fiber and Its Application as Concrete Reinforcing Fiber. Cement and Concrete Compositions. Cement and Concrete Composites, 29. pp 448-455.

[8]. D.A. Silva, A. M. Betioli, P. J. P. Gleize, H. R. Roman, L. A. Gomez, J. L. D. Ribeiro. 2005. Degradation of Recycled PET Fibers in Portland Cement-Based Materials. Cement and Concrete Research, Volume 35, Issue 9. pp 1741-1746

[9]. D. Foti. 2011. Preliminary Analyses of Concrete Reinforced with Waste Bottles PET Fibers. Construction and Building Materials, Volume 25, Issue 4. pp 1906-1915.
[10]. S. H. Kosmatka, B. Kerkhoff, R. D. Hooton, and R. J. McGrath, Design and Control of Concrete Mixtures, EB101, 8th edition, Cement Association of Canada, Ottawa, Ontario, Canada 2010.

[11]. CSA A23.2-5C. 2012. Slump and Slump Flow of Concrete. Canadian Standard Association, Toronto, Canada [12]. CSA A23.2-3C. 1990. Making and Curing Concrete Compression and Flexural Test Specimens. Canadian Standard Association, Toronto, Canada

[13]. CSA A23.2-9C. 2012. Compressive Strength of Cylindrical Concrete Specimens. Canadian Standard Association, Toronto, Canada

[14]. CSA A23.2-13C. 1990. Splitting Tensile Strength of Cylindrical Concrete Specimens. Canadian Standard Association, Toronto, Canada

[15]. CSA A23.2-8A. 1990. Flexural Strength of Concrete (Using Simple Beam with Third-Point Loading). Canadian Standard Association, Toronto, Canada

[16]. Wafa, F. F. Properties and Applications of Fiber Reinforced Concrete. JKAU: Eng. Sci., Vol. 2. pp 49-63 